Article

\title{
Effects of the Biofertilizer OYK (Bacillus sp.) Inoculation on Endophytic Microbial Community in Sweet Potato
}

\author{
Ahsanul Salehin ${ }^{1}$, Md Hafizur Rahman Hafiz ${ }^{2,3}$, Shohei Hayashi ${ }^{2}$, Fumihiko Adachi ${ }^{2}$ and \\ Kazuhito Itoh $1,2, *$ (D) \\ 1 The United Graduate School of Agricultural Sciences, Tottori University, 4-101 Koyama-minami, \\ Tottori 680-8553, Japan; ujanrijvi224@gmail.com \\ 2 Faculty of Life and Environmental Sciences, Shimane University, 1060 Nishikawatsu, Matsue, \\ Shimane 690-8504, Japan; hafizhstu@hotmail.com (M.H.R.H.); shohaya@life.shimane-u.ac.jp (S.H.); \\ fadachi@life.shimane-u.ac.jp (F.A.) \\ 3 Department of Crop Physiology and Ecology, Hajee Mohammad Danesh Science and Technology University, \\ Dinajpur 5200, Bangladesh \\ * Correspondence: itohkz@life.shimane-u.ac.jp; Tel.: +81-852-32-6521
}

Received: 2 October 2020; Accepted: 9 November 2020; Published: 12 November 2020

\begin{abstract}
Sweet potato (Ipomoea batatas L.) grows well even in infertile and nitrogen-limited fields, and endophytic bacterial communities have been proposed to be responsible for this ability. Plant-growth-promoting bacteria are considered eco-friendly and are used in agriculture, but their application can interact with endophytic communities in many ways. In this study, a commercial biofertilizer, OYK, consisting of a Bacillus sp., was applied to two cultivars of sweet potato, and the effects on indigenous endophytic bacterial communities in field conditions were examined. A total of 101 bacteria belonging to 25 genera in 9 classes were isolated. Although the inoculated OYK was not detected and significant plant-growth-promoting effects were not observed, the inoculation changed the endophytic bacterial composition, and the changes differed between the cultivars, as follows: Novosphingobium in $\alpha$-Proteobacteria was dominant; it remained dominant in Beniharuka after the inoculation of OYK, while it disappeared in Beniazuma, with an increase in Sphingomonas and Sphingobium in $\alpha$-Proteobacteria as well as Chryseobacterium and Acinetobacter in Flavobacteria. The behavior of Bacilli and Actinobacteria also differed between the cultivars. The Shannon diversity index $(H)$ increased after inoculation in all conditions, and the values were similar between the cultivars. Competition of the inoculant with indigenous rhizobacteria and endophytes may determine the fates of the inoculant and the endophytic community.
\end{abstract}

Keywords: OYK; biofertilizers; PGPR; sweet potato; endophytes; microbial community; shannon diversity index

\section{Introduction}

Modern agriculture systems are being intensified through the use of various technologies to achieve maximum efficiency and high qualify products to meet the growing global demand for food supply [1]. At present, as a part of agricultural intensification, crop production depends on the large-scale use of chemical fertilizers [2]. However, the intensive use of chemical fertilizers can result in considerable negative environmental impacts and pollution [3]. Therefore, an alternative strategy is urgently needed to establish sustainable agriculture and ecological balance in agro-ecosystems.

Plant-growth-promoting rhizobacteria (PGPR) are free-living soil bacteria that enhance plant growth by colonizing the rhizosphere [4]. PGPR regulate nutritional and hormonal balance, produce 
phytohormones, solubilize nutrients, and induce resistance to plant pathogens [5]. Therefore, PGPR have been used as biofertilizers and/or bioenhancers, as an alternative source of chemical fertilizers to improve soil quality and sustainability and to increase crop production [6-8]. The application of PGPR has become a more broadly recognized practice for the enrichment of sustainable agricultural production in several parts of the world.

Sweet potato (Ipomoea batatas L.) is a resilient, easily propagated crop, and its roots are largely used for food consumption. More than $95 \%$ of the global sweet potato crop is produced in developing countries, and it has vast economic and social importance [9,10]. It is also well-known for its ability to grow well even in infertile and nitrogen-limited fields [11,12], and nitrogen fixation by endophytic bacteria has been proposed to contribute to this attribute [13].

Endophytes are known to promote plant growth by producing phytohormones [14-16] and siderophores $[17,18]$ and through nitrogen fixation [19]. It has also been reported that some endophytes can protect plants by producing antipathogenic substances [20], ameliorating disease development [21], and inducing stress tolerance [22]. Therefore, an understanding of the endophyte-plant interaction is essential for developing sustainable systems of crop production [23].

Diverse endophytic bacteria have been isolated from sweet potato; such bacteria include Gluconacetobacter, Klebsiella, and Pantoea [24,25], as well as Enterobacter, Rahnella, Rhodanobacter, Pseudomonas, Stenotrophomonas, Xanthomonas, and Phyllobacterium [26]. Marques et al. [27] and Puri et al. [28] reported 93 and 243 endophytic bacterial strains belonging to 17 and 34 genera in Brazilian and Nepalese sweet potatoes, respectively. Among these isolates of sweet potato bacterial endophytes, many strains had beneficial properties, such as nitrogen fixation, auxin production, antagonistic effects, phosphate solubilization, and siderophore production.

It is speculated that the beneficial functions of endophytes are realized when a suitable endophytic community is established, and it is expected that the inoculation of PGPR has synergic or competitive effects on the composition and function of the endophytic community [29]. However, to the best of our knowledge, only a few studies are available on this subject. Conn and Franco [30] showed that the inoculation of a nonadapted microbial inoculum into the soil disrupted the natural actinobacterial endophyte population of wheat plants and reduced their diversities and colonization levels, whereas the inoculation of a single actinobacterial endophyte did not affect the indigenous endophyte population. Gadhave et al. [31] reported that seed and soil inoculations of Bacillus spp. changed the composition of the endophytic bacterial community of sprouting broccoli and increased its diversity, as established through the metagenomic approach.

In the present study, we treated sweet potato with a commercial biofertilizer, OYK, consisting of a Bacillus strain, which was reported to induce plant tolerance to abiotic and/or biotic stresses and to have antimicrobial activities against pathogens [32]. We then examined culturable endophytic communities at harvest in order to obtain further information on the effects of PGPR inoculation on indigenous endophytic bacterial communities in field conditions.

\section{Materials and Methods}

\subsection{Growth Condition, Inoculation, and Cultivation of Sweet Potato}

Two cultivars of sweet potato, Beniazuma (A) and Beniharuka $(\mathrm{H})$, were used in this study. OYK Farming Ace (Hamaguchi Institute of Microbiology Inc., Kyoto, Japan, http://www.oyk.jp/), consisting of about 8E $+9 \mathrm{CFU} / \mathrm{mL}$ endospores of one Bacillus sp. strain (LC590219), was used as PGPR, according to the manufacturer's instruction. One milliliter of OYK solution was diluted to $4 \mathrm{~L}$ with sterilized distilled water, and twelve seedlings of each cultivar were dipped in the solution for $60 \mathrm{~h}(\mathrm{O})$. The same numbers of the seedlings were soaked in distilled water as a control (C). These seedlings were transplanted at random at $20 \mathrm{~cm}$ intervals on ridges with $1 \mathrm{~m}$ spacing in a rooftop experimental field [33] at Shimane University in Shimane, Japan. The field was filled with artificial soil (Viva soil; Toho Leo Co., Osaka, Japan) that had high porosity (45\%) and contained very little nutrition, and a 
chemical fertilizer $\left(\mathrm{N}: \mathrm{P}_{2} \mathrm{O}_{5}: \mathrm{K}_{2} \mathrm{O}=4: 8: 15 \mathrm{~g} / \mathrm{m}^{2}\right)$ was applied before planting. The plants were cultivated from June to November in 2015 with drip irrigation (Super Typhoon NETAFIM Co., Tel Aviv, Israel).

\subsection{Sample Collection and Isolation of Endophytic Bacteria}

At harvest, the fresh weights of the shoots and tubers of each sweet potato plant were measured. Culturable endophytes of sweet potato tubers were examined; among the plant parts, the highest population was observed in tubers in our previous study [34]. The surface of each tuber sample was washed with running tap water for $10 \mathrm{~min}$ and cut longitudinally with a sterilized knife at its middle part after wiping off the water with a paper towel. Then, the cut surface was stamped on modified MR agar medium, with and without the supplementation of ammonium nitrate as a nitrogen source [35] in a petri dish. The ingredients of the media are listed in Supplementary materials Table S1. The efficiency of the washing procedure was evaluated by stamping the surface of the washed tubers on agar media. After incubation for 2 days at ca. $26{ }^{\circ} \mathrm{C}$, all the bacterial colonies were transferred to either $\mathrm{N}$-supplemented or N-free MR media for purification and then grouped based on their morphologies on the two media. Based on their relative abundance, 1-3 representative isolates from each group, comprising $30-81 \%$ of total isolates, were selected for further analysis (Table 1).

Table 1. Number of isolated endophytic bacterial strains of sweet potato, types of morphologies on the agar plates, and strains selected for sequence analysis.

\begin{tabular}{cccccc}
\hline Sample $^{\mathbf{a}}$ & CFU $^{\mathbf{b}}$ & Isolated $^{\mathbf{c}}$ & Morphology $^{\mathbf{d}}$ & Selected $^{\mathbf{e}}$ & Identified $^{\mathbf{f}}$ \\
\hline $\mathrm{AO}-\mathrm{N}(+)$ & 32 & 32 & 11 & 14 & 14 \\
$\mathrm{AO}-\mathrm{N}(-)$ & 42 & 40 & 17 & 17 & 17 \\
$\mathrm{AC}-\mathrm{N}(+)$ & 22 & 13 & 6 & 10 & 10 \\
$\mathrm{AC}-\mathrm{N}(-)$ & 24 & 18 & 9 & 12 & 11 \\
$\mathrm{HO}-\mathrm{N}(+)$ & 50 & 50 & 12 & 15 & 13 \\
$\mathrm{HO}-\mathrm{N}(-)$ & 46 & 42 & 14 & 15 & 12 \\
$\mathrm{HC}-\mathrm{N}(+)$ & 31 & 21 & 11 & 13 & 13 \\
$\mathrm{HC}-\mathrm{N}(-)$ & 22 & 16 & 11 & 13 & 11 \\
\hline Total & 269 & 232 & - & 109 & 101 \\
\hline
\end{tabular}

a Endophytic strains were isolated from the sweet potato cultivars, Beniazuma (A) and Beniharuka (H). Sweet potato seedlings were inoculated with OYK $(\mathrm{O})$ as PGPR or with distilled water as the control (C). The modified MR agar medium was used for isolation, with nitrogen supplementation $(\mathrm{N}(+))$ or without a nitrogen $(\mathrm{N}(-))$ source. ${ }^{\mathrm{b}}$ Number of colonies that appeared on the original agar plates. ${ }^{c}$ Number of successfully isolated colonies. ${ }^{\mathrm{d}}$ Number of morphologies observed. ${ }^{\text {e }}$ Number of isolates selected based on the relative abundances of morphologies for sequence analysis. ${ }^{\mathrm{f}}$ Number of strains successfully sequenced.

\subsection{Genetic Analysis of Endophytes}

Genomic DNA was extracted from each isolate, as described by Saeki et al. [36], with slight modifications, and used as a template for PCR for the amplification of the partial 16S rRNA gene sequence. As an indication of the dinitrogen-fixing potential of the isolates, nifH genes, which encode nitrogenase reductase, were PCR-amplified, for which a small amount of culture was directly used as a template. The primers used were fD1 and rP2 [37] and PolF and PolR [38] for the 16S rRNA and nifH genes, respectively. The components of the PCR master mixtures and the PCR running conditions are summarized in Supplementary materials Table S2. PCR products were purified and subjected to PCR cycle sequencing, according to the procedures described previously [39].

The closest sequence in the database (https://www.ddbj.nig.ac.jp/) was determined by a BLAST [40] search, and multiple sequence alignments were constructed using ClustalW 2.1 [41]. Alignments were manually edited, and phylogenetic trees with the related reference genes were constructed using ClustalW 2.1 with the neighbor-joining method. 


\subsection{Analysis of the Community Structure of Endophytes}

Based on the results of the BLAST search and phylogenetic analysis, relative abundance (\%) was calculated according to the class and genus of the identified bacteria for each sample, reflecting the relative abundance on the plate (Table 1). These results were used to analyze the effects of OYK inoculation, the difference between the presence and absence of a nitrogen source in the medium, and the two sweet potato cultivars on the community structure of the endophytes. Principal component analysis (PCA) was applied on a genera basis using IBM SPSS Statistics ver. 25 (IBM Co., Armonk, NY, USA).

\subsection{Nucleotide Sequence Accession Numbers}

The sequence data generated in this study were deposited in the DDBJ Nucleotide Submission System under the accession numbers LC583148 to LC583248.

\subsection{Statistical Analysis}

Statistical analysis of the sweet potato cultivation data was performed using Student's $t$-test. The Shannon diversity index $\left(H^{\prime}\right)$ was calculated based on the identified genus to characterize the diversities in the endophytic bacterial communities.

\section{Results}

\subsection{Effects of OYK Inoculation}

In terms of the dry weights of shoots and tubers, the growth of sweet potato cultivar Beniharuka was better than that of Beniazuma, and there was no significant difference between samples with and without OYK inoculation in either cultivar (Figure 1).
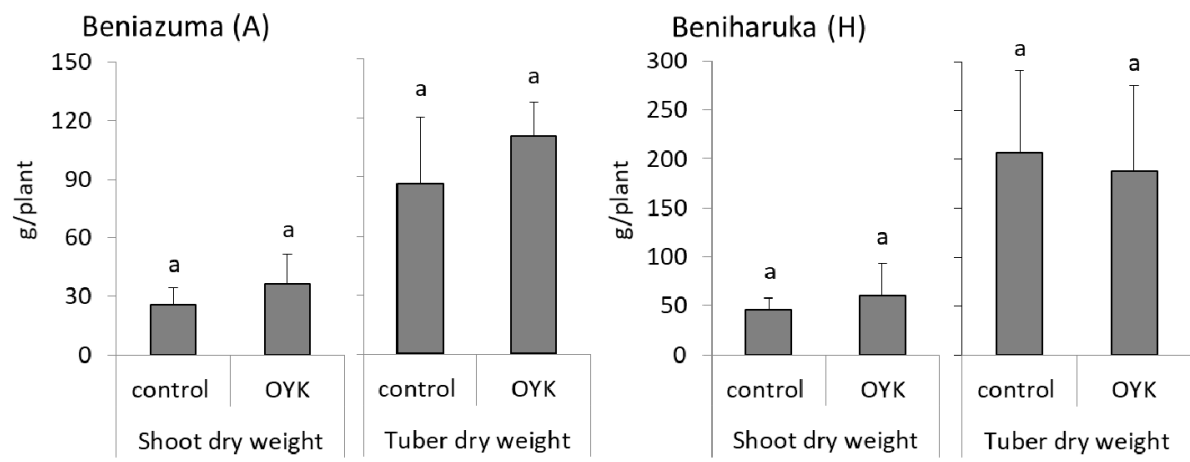

Figure 1. Dry weight of two sweet potato cultivars, Beniazuma (A) and Beniharuka $(\mathrm{H})$, inoculated with OYK as PGPR, compared with the control. The bars represent standard deviation $(\mathrm{n}=3)$, and different letters indicate significant differences at $p<0.05$ by Student's $t$-test.

\subsection{Isolation of Endophytic Bacterial Strains}

Originally, 269 bacterial colonies appeared on the agar plates in total, of which 232 strains were successfully isolated. On the basis of their observed morphologies on the modified MR agar medium, with and without nitrogen supplementation, the isolates were grouped into 6-17 groups in each sample. Based on their relative abundance, 1-3 representative isolates were selected from each group, comprising $30-81 \%$ of the original isolates; as a result, 109 isolates were selected, in total, for further analysis (Table 1). 


\subsection{Genetic Analysis of Endophytes}

Among the 109 selected endophytic bacterial isolates, 101 strains were successfully sequenced for the partial 16S rRNA gene. The results of the closest relatives in the DDBJ database are presented in Supplementary materials Table S3 and Figure S1 and summarized in Table 2 and Figure 2. The isolates belonged to 25 bacterial genera in 9 classes, which showed 97-100\% homology. Among the 101 identified bacterial strains, 55 representative strains from each genus in each sample were subjected to PCR for the nifH gene; however, none of the strains produced positive amplification, with Bradyrhizobium elkanii USDA 94 used as a positive control.

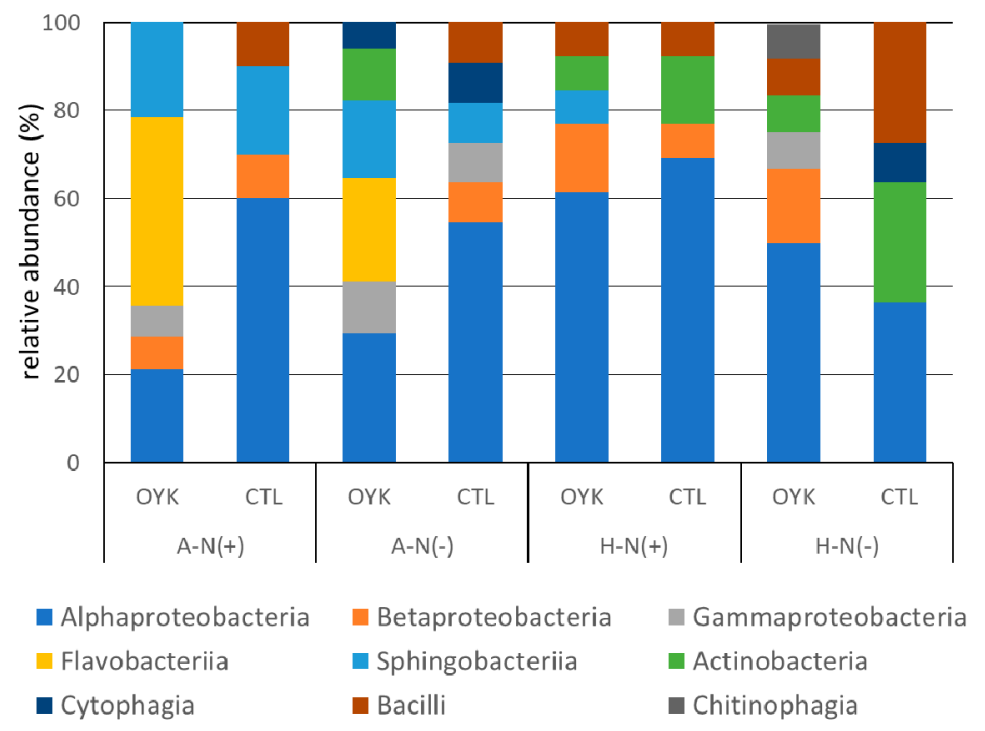

Figure 2. Relative class composition of endophytes of two sweet potato cultivars, Beniazuma (A) and Beniharuka $(\mathrm{H})$, inoculated with OYK as PGPR, compared with the control. Bacteria were cultured using a modified MR medium, with and without a supplemental nitrogen source.

\subsection{Community Structure of Endophytes}

In control samples, $\alpha$-Proteobacteria predominated (36-69\%) in both cultivars, in which Novosphingobium sp. was dominant (36-54\%). After the inoculation of OYK, the fate of Novosphingobium sp. was different between the cultivars. In Beniazuma, Novosphingobium sp. disappeared, while it remained (25-38\%) in Beniharuka. Rhizobium sp. in $\mathrm{N}(+)$ disappeared in both cultivars after inoculation. With the disappearance of or decrease in Novosphingobium sp. and Rhizobium sp., two other genera in $\alpha$-Proteobacteria, Sphingomonas sp. (6-21\%) and Sphingobium sp. (8-15\%), newly appeared, and Chryseobacterium sp. (21-24\%) and Acinetobacter sp. (21\%) in Flavobacteriia also appeared in Beniazuma. Bacilli (8-10\%) disappeared only in Beniazuma after inoculation, while it persisted in Beniharuka. While Sphingobacteriia tended to be detected in Beniazuma (9-21\%), Actinobacteria was detected in Beniharuka (8-27\%), and $\beta$-Proteobacteria was similarly detected in both cultivars (7-17\%).

To further elucidate the influence of the OYK inoculation, PCA was conducted to evaluate the relative abundance of the endophytic genera in Table 2. The first and second component factors explained $61.1 \%$ and $13.8 \%$ of the variation, respectively (Figure 3). All control samples, including both cultivars and both media conditions, were positioned close to each other, while the OYK-inoculated samples were positioned farther apart for each cultivar, especially in Beniazuma. The effects of the presence or absence of nitrogen in the media were not apparent. 
Table 2. Relative abundance (\%) of endophytes from two cultivars of sweet potato, with and without OYK inoculation as PGPR. Bacteria were cultured using a modified MR medium, with and without a supplemental nitrogen source.

\begin{tabular}{|c|c|c|c|c|c|c|c|c|}
\hline \multirow{3}{*}{ Class/Genus } & \multicolumn{4}{|c|}{ Beniazuma (A) } & \multicolumn{4}{|c|}{ Beniharuka (H) } \\
\hline & \multicolumn{2}{|c|}{$N(+)$} & \multicolumn{2}{|c|}{ N (-) } & \multicolumn{2}{|c|}{$\mathrm{N}(+)$} & \multicolumn{2}{|c|}{$\mathbf{N}(-)$} \\
\hline & OYK & CTL & OYK & CTL & OYK & CTL & OYK & CTL \\
\hline$\alpha$-Proteobacteria & 21 & 60 & 29 & 55 & 62 & 69 & 50 & 36 \\
\hline Novosphingobium & - & 50 & - & 45 & 38 & 54 & 25 & 36 \\
\hline Rhizobium & - & 10 & 6 & - & - & 15 & - & - \\
\hline Sphingomonas & 21 & - & 6 & - & 8 & - & 8 & - \\
\hline Sphingobium & - & - & 12 & - & 15 & - & 8 & - \\
\hline Caulobacter & - & - & 6 & 9 & - & - & 8 & - \\
\hline$\beta$-Proteobacteria & 7 & 10 & - & 9 & 15 & 8 & 17 & - \\
\hline Methylibium & - & 10 & - & - & - & - & - & - \\
\hline Burkholderia & - & - & - & 9 & - & - & - & - \\
\hline Variovorax & 7 & - & - & - & 8 & 8 & - & - \\
\hline Mitsuaria & & - & - & - & 8 & - & 17 & \\
\hline$\gamma$-Proteobacteria & 7 & - & 12 & 9 & - & - & 8 & - \\
\hline Pseudoxanthomonas & 7 & - & - & - & - & - & 8 & - \\
\hline Stenotrophomonas & - & - & 6 & - & - & - & - & - \\
\hline Pseudomonas & - & - & 6 & - & - & - & - & - \\
\hline Dyella & - & - & - & 9 & - & - & - & - \\
\hline Flavobacteria & 43 & - & 24 & - & - & - & - & - \\
\hline Chryseobacterium & 21 & - & 24 & - & - & - & - & - \\
\hline Acinetobacter & 21 & - & - & - & - & - & - & - \\
\hline Sphingobacteria & 21 & 20 & 18 & 9 & 8 & - & - & - \\
\hline Mucilaginibacter & - & 20 & - & 9 & 8 & - & - & - \\
\hline Sphingobacterium & 21 & - & - & - & - & - & - & - \\
\hline Pedobacter & - & - & 18 & - & - & - & - & - \\
\hline Actinobacteria & - & - & 12 & - & 8 & 15 & 8 & 27 \\
\hline Microbacterium & - & - & - & - & 8 & 15 & 8 & 27 \\
\hline Streptomyces & - & - & 6 & - & - & - & - & - \\
\hline Lysinimonas & - & - & 6 & - & - & - & - & - \\
\hline Cytophagia & - & - & 6 & 9 & - & - & - & 9 \\
\hline Dyadobacter & - & - & 6 & - & - & - & - & 9 \\
\hline Chryseolinea & - & - & - & 9 & - & - & - & - \\
\hline Bacilli & - & 10 & - & 9 & 8 & 8 & 8 & 27 \\
\hline Bacillus & - & 10 & - & 9 & 8 & 8 & 8 & 27 \\
\hline Chitinophagia & - & - & - & - & - & - & 8 & - \\
\hline Filimonas & - & - & - & - & - & - & 8 & - \\
\hline
\end{tabular}




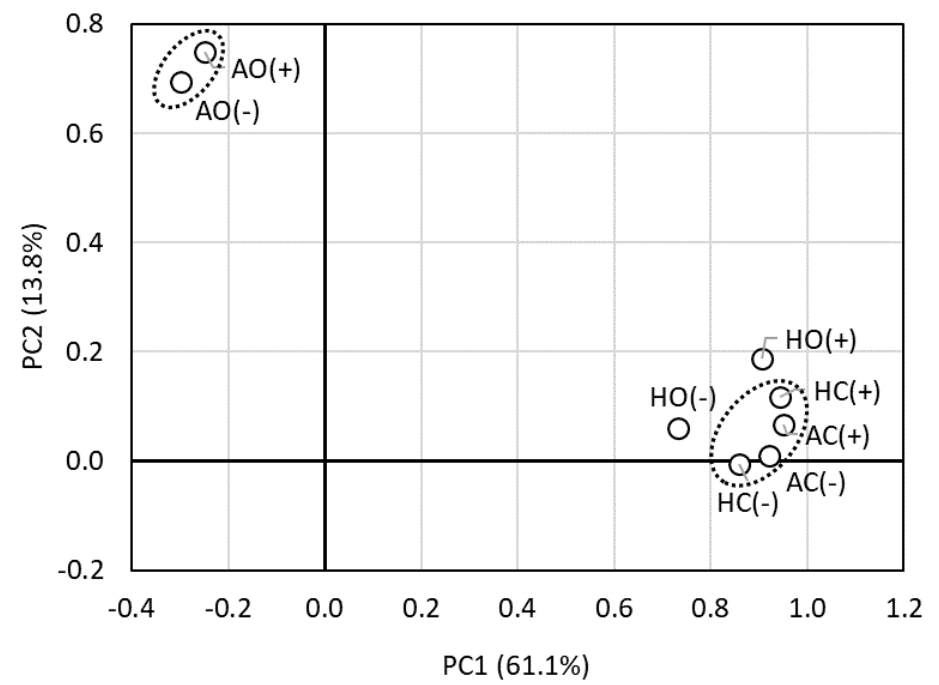

Figure 3. Principal component analysis (PCA) of endophytic communities of two sweet potato cultivars, Beniazuma (A) and Beniharuka $(\mathrm{H})$, inoculated with OYK $(\mathrm{O})$ as PGPR, compared with the control (C). Bacteria were cultured using a modified MR medium, with (+) and without (-) a supplemental nitrogen source. PCA was performed based on the bacterial genera in Table 2.

\subsection{Diversity of Endophytes}

Shannon diversity indices $(H)$, calculated on the genus level, were increased with the inoculation of OYK in all conditions (Figure 4 and Supplementary materials Figure S2). The increase appeared to be larger in endophytic communities that were isolated using nitrogen-free media, although the indices were similar among the control samples. No difference between the cultivars was apparent.

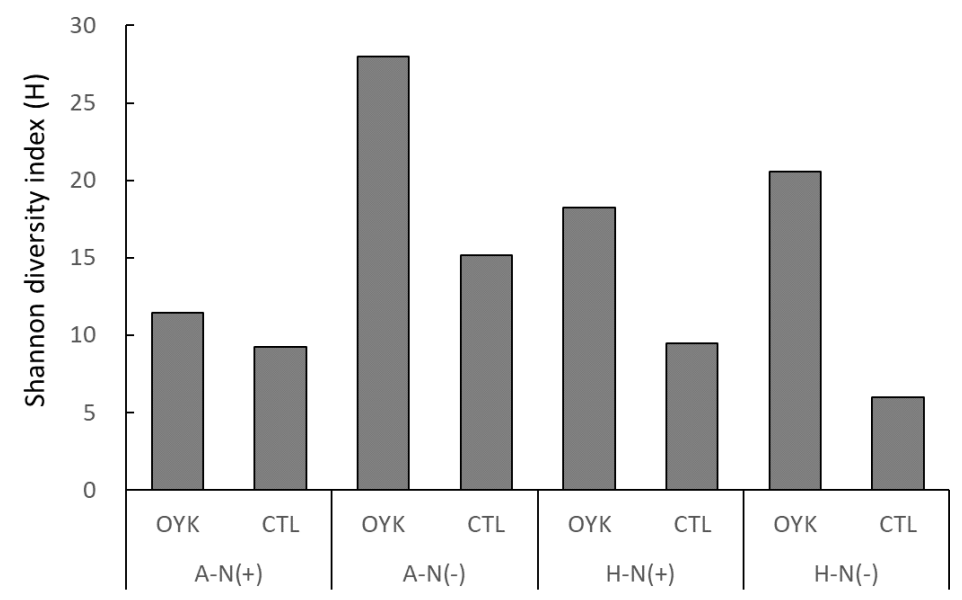

Figure 4. Shannon diversity index $(\mathrm{H})$ of endophytic communities of two sweet potato cultivars, Beniazuma (A) and Beniharuka (H), inoculated with OYK as PGPR, compared with the control. Bacteria were cultured using a modified MR medium, with and without a supplemental nitrogen source.

\section{Discussion}

Bacillus strains have been well recognized as PGPR for their plant-growth-promoting performance in sweet potato [8], tomato [42-45], mulberry [46], lettuce [47], wheat [48], pepper [49], potato [50], tobacco [6,51], and saffron [52], as well as their antimicrobial activities against pathogens [27,28], and they are commercially available for their potential use in agriculture [53,54]. However, in our study, the PGPR properties of OYK were not observed (Figure 1). One possible reason might be that the 
inoculated OYK disappeared during the cultivation due to environmental factors and competition with indigenous rhizobacteria, as discussed below.

The endophytic community structure has been reported to be determined by several factors, such as plant genotype, soil type [55], and environmental conditions, as well as stochastic sampling factors [56]. In the present study, analysis of the bacterial endophytes of sweet potato revealed that Proteobacteria was the dominant phylum in the communities, followed by Flavobacteria, Sphingobacteria, Actinobacteria, and Bacilli. $\alpha$-Proteobacteria was the dominant class in Proteobacteria, followed by $\beta$ - and $\gamma$-Proteobacteria (Table 2). In previous studies of sweet potato endophytes, Proteobacteria, including $\alpha-, \beta-$, and $\gamma$-Proteobacteria, Flavobacteria, Actinobacteria, and Bacilli were also predominant among isolates $[27,28,57]$. These results suggest that the endophytic community of sweet potato consists of bacteria belonging to common phyla.

Almost all of the detected genera in Proteobacteria, Actinobacteria, and Bacilli have been reported as endophytes in sweet potato $[27,28,57]$ except for Novosphingobium sp., which was the dominant genus in most samples. The other dominant genera in our study, Chryseobacterium sp., Acinetobacter sp., Mucilaginibacter sp., and Sphingobacterium sp., have not been reported as endophytes. The genera in Flavobacteria and Sphingobacteria were isolated from the cultivar Beniazuma, suggesting that these isolates were sweet potato cultivar-dependent. Differences in endophytic and rhizosphere bacterial communities among sweet potato cultivars have also been demonstrated [27,58]. On the other hand, the common dominant genera in the other studies, Enterobacter sp., Pantoea sp., Luteibacter sp., Herbaspirillum sp., and Curtobacterium sp., were not isolated in our study, suggesting the presence of diverse bacterial endophytes of sweet potato, with some common genera.

The inoculation of OYK changed the composition of the indigenous bacterial endophytic communities on both the phylum and genus levels, though OYK itself failed to maintain a population as an endophyte. The effects were similar between $\mathrm{N}(+)$ and $\mathrm{N}(-)$ media, while they were different between the Beniazuma (A) and Beniharuka (H) cultivars, especially for Novosphingobium sp., which was dominant in all control samples and disappeared in Beniazuma (A) while remaining predominant in Beniharuka (H). Flavobacteria and Sphingobavteria in Beniazuma (A) only appeared after the inoculation of OYK, which could have caused the change in the community structures found in PCA (Figure 3). Although only one sample of the sweet tuber was used for each cultivar and media condition, the closer positions of the control samples indicate that variability in the community structures of the control samples was within a certain range and that the different positions in PCA were caused by the inoculation of OYK. These results suggest that interactive endophytic bacterial behavior might be influenced by the cultivar of sweet potato. It has been reported that the plant cultivar and genotype affect communities of rhizobacteria, presumably as a result of competition for different root exudates [59-61]. Differences in a rhizobacterial community might affect the corresponding endophytic community as a result. Germida et al. [62] compared rhizoplane and endophytic bacteria strains that were isolated from canola plants and suggested that endophytes are a subset of the rhizoplane community. Additionally, differences in nutritional compositions of endophytic environments will also affect the community through competition.

In a seed and soil inoculation experiment with Bacillus spp., the Bacillus inocula failed to establish as endophytes in broccoli roots, as in our study, and the main effects of the Bacillus inoculation were a reduction in Lysobacter and Acidovorax and an increase in Acinetobacter, as analyzed by metagenomic sequencing [31]. The authors also reported that the addition of $B$. amyloliquefaciens influenced the endophytic microbial community: the most common Pseudomonas endophytes decreased in abundance, accompanied by an increase in Dyadobacter, Variovorax, Tahibacter, and Sphingomonas. In contrast, the inoculation of B. cereus and B. subtilis did not affect the population of Pseudomonas though it changed the endophytic community composition of minor genera. Although the genera affected by the Bacillus inoculation were different from those in our study, the results obtained by culture-dependent and -independent studies suggest that a microbial inoculation can change an endophytic microbial community, even if the inoculant cannot establish a population as an endophyte. As many studies 
have shown the importance of endophytes for plant growth promotion, elucidating the interaction mechanisms is an essential line of research.

Although Bacillus spp. have been reported as indigenous endophytes in sweet potato $[28,57,58]$ and in other crops such as tomato [63], banana [64], canola [62], and switchgrass [65], the inoculated OYK and Bacillus spp. strains [31] could not establish populations as endophytes. On the other hand, the inoculation of endophytic Bacillus subtilis, isolated from wheat, could establish a population in wheat root and showed potential as a biological control against plant pathogens [66]. Changes in the compositions of plant metabolites and root exudates that would be caused by OYK might directly change indigenous rhizospheric and endophytic microbial communities and/or might indirectly prevent the successful colonization of OKY due to competition with microbial communities for compounds. As OYK was isolated from the soil, the endophytic potential of an inoculant, whether it was originally isolated as an endophyte, seems to be important.

The Shannon diversity index $(H)$ of the isolated endophytic community increased with OYK inoculation (Figure 3). The tendency was the same as that in the results obtained by Gadhave et al. [31], who also reported an increase in diversity in both Bacillus amyloliquefaciens- and mixed Bacillus spp.-treated sprouting broccoli, examined by a culture-independent metagenomic approach. In both studies, using different approaches, the number of genera identified increased with the inoculation; however, the mechanisms are still unclear.

Supplementary Materials: The following are available online at http://www.mdpi.com/2311-7524/6/4/81/s1, Figure S1: Phylogenetic tree of endophytes of sweet potato cultivars, Beniazuma (A) and Beniharuka $(\mathrm{H})$, inoculated with PGPR, OYK compared with control, using modified MR medium supplemented with and without nitrogen source based on partial 16S rRNA gene sequences, Figure S2: Relative genus composition of endophytes of sweet potato cultivars, Beniazuma (A) and Beniharuka $(\mathrm{H})$, inoculated with PGPR, OYK compared with control, using modified MR medium supplemented with and without nitrogen source, Table S1: Ingredients of modified MR (N-free MR) agar medium, Table S2: PCR ingredients for amplification of 16S rRNA and nifH genes, Table S3: Closest relatives of endophytic bacterial strains from two cultivars of sweet potato inoculated with and without PGPR, OYK, using modified MR medium supplemented with and without nitrogen source.

Author Contributions: A.S. and K.I. conceptualized the study and designed the experiments; A.S. performed the experiments; the field experiment was performed by F.A. and S.H.; M.H.R.H. assisted in the experiment, data recording, and analysis; A.S. wrote the article, with a substantial contribution from K.I. All authors have read and agreed to the published version of the manuscript.

Funding: This research received no external funding.

Conflicts of Interest: The authors declare no conflict of interest.

\section{References}

1. Tilman, D.; Balzer, C.; Hill, J.; Befort, B.L. Global food demand and the sustainable intensification of agriculture. Proc. Natl. Acad. Sci. USA 2011, 108, 20260-20264. [CrossRef] [PubMed]

2. Adesemoye, A.O.; Torbert, H.A.; Kloepper, J.W. Plant growth-promoting rhizobacteria allow reduced application rates of chemical fertilizers. Microb. Ecol. 2009, 58, 921-929. [CrossRef] [PubMed]

3. Silva, L.F.O.; Hower, J.C.; Izquierdo, M.; Querol, X. Complex nanominerals and ultrafine particles assemblages in phosphogypsum of the fertilizer industry and implications on human exposure. Sci. Total Environ. 2010, 408, 5117-5122. [CrossRef] [PubMed]

4. Ashrafuzzaman, M.; Hossen, F.A.; Ismail, M.R.; Hoque, M.A.; Islam, M.Z.; Shahidullah, S.M.; Meon, S. Efficiency of plant growth-promoting rhizobacteria (PGPR) for the enhancement of rice growth Afr. J. Biotechnol. 2009, 8, 1247-1252.

5. Nadeem, S.M.; Ahmad, M.; Zahir, Z.A.; Javaid, A.; Ashraf, M. The role of mycorrhizae and plant growth promoting rhizobacteria (PGPR) in improving crop productivity under stressful environments. Biotechnol. Adv. 2014, 32, 429-448. [CrossRef] [PubMed]

6. Li, X.; Wu, Z.; Li, W.; Yan, R.; Li, L.; Li, Y.; Li, M. Growth promoting effect of a transgenic Bacillus mucilaginosus on tobacco planting. Appl. Microbiol. Biotechnol. 2007, 74, 1120-1125. [CrossRef] [PubMed] 
7. Nosratabad, A.R.F.; Etesami, H.; Shariati, S. Integrated use of organic fertilizer and bacterial inoculant improves phosphorus use efficiency in wheat (Triticum aestivum L.) fertilized with triple superphosphate. Rhizosphere 2017, 3, 109-111. [CrossRef]

8. Dawwam, G.E.; Elbeltagy, A.; Emara, H.M.; Abbas, I.H.; Hassan, M.M. Beneficial effect of plant growth promoting bacteria isolated from the roots of potato plant. Annal. Agric. Sci. 2013, 58, 195-201. [CrossRef]

9. Reiter, B.; Burgmann, H.; Burg, K.; Sessitsch, A. Endophytic gene diversity in African sweet potato. Can. J. Microbiol. 2003, 49, 549-555. [CrossRef]

10. Souza, V.C.; Lorenzi, H. Botânica sistemática. In Guia Ilustrado Para Identificação das Famílias de Angiospermas da Flora Brasileira; Souza, V.C., Lorenzi, H., Eds.; Instituto Plantarum: Nova Odessa, Brazil, 2008; p. 640.

11. Hartemink, A.E.; Poloma, S.; Maino, M.; Powell, K.S.; Egenae, J.; O’Sullivan, J.N. Yield decline of sweet potato in the humid lowlands of Papua New Guinea. Agric. Ecosyst. Environ. 2000, 79, 259-269. [CrossRef]

12. Hill, W.A.; Hortense, D.; Hahn, S.K.; Mulongoy, K.; Adeyeye, S.O. Sweet potato root and biomass production with and without nitrogen fertilization. Agron. J. 1990, 82, 1120. [CrossRef]

13. Yonebayashi, K.; Katsumi, N.; Nishi, T.; Okazaki, M. Activation of nitrogen-fixing endophytes is associated with the tuber growth of sweet potato. Mass Spectrom. 2014, 3, 1-4. [CrossRef] [PubMed]

14. Jacobson, C.B.; Pasternak, J.J.; Glick, B.R. Partial purification and characterization of 1-aminocyclopropane-1-carboxylate deaminase from the plant growth promoting rhizobacterium Pseudomonas putida GR 12-2. Can. J. Microbiol. 1994, 40, 1019-1025. [CrossRef]

15. Dhungana, S.A.; Adachi, F.; Hayashi, S.; Puri, R.R.; Itoh, K. Plant growth promoting effects of Nepalese sweet potato endophytes. Horticulturae 2018, 4, 53. [CrossRef]

16. Gamalero, E.; Glick, B.R. Bacterial modulation of plant ethylene levels. Plant Physiol. 2015, 169, 13-22. [CrossRef]

17. O'Sullivan, D.J.; O'Gara, F. Traits of fluorescent Pseudomonas spp. involved in suppression of plant root pathogens. Microbiol. Rev. 1992, 56, 662-676. [CrossRef]

18. Khan, M.S.; Gao, J.; Chen, X.; Zhang, M.; Yang, F.; Du, Y.; Moe, T.S.; Munir, I.; Xue, J.; Zhang, X. Isolation and characterization of plant growth-promoting endophytic bacteria Paenibacillus polymyxa SK1 from Lilium lancifolium. Biomed. Res. Int. 2020, 8650957. [CrossRef]

19. Terakado-Tonooka, J.; Fujihara, S.; Ohwaki, Y. Possible contribution of Bradyrhizobium on nitrogen fixation in sweet potatoes. Plant Soil 2013, 367, 639-650. [CrossRef]

20. Bangera, M.G.; Thomashow, L.S. Characterization of a genomic locus required for synthesis of the antibiotic 2, 4-diacetylphloroglucinol by the biological control agent Pseudomonas fluorescens Q2-87. Mol. Plant Microbe. Interact. 1996, 9, 83-90. [CrossRef]

21. Benhamou, N.; Kloepper, J.W.; Quadt-Hallman, A.; Tuzun, S. Induction of defence related ultrastructural modifications in pea root tissues inoculated with endophytic bacteria. Plant Physiol. 1996, 112, 919-929. [CrossRef]

22. Hallmann, J.; Quadt-Hallmann, A.; Mahaffee, W.F.; Kloepper, J.W. Bacterial endophytes in agricultural crops. Can. J. Microbiol. 1997, 43, 895-914. [CrossRef]

23. Sturz, A.V.; Christie, B.R.; Nowak, J. Bacterial endophytes: Potential role in developing sustainable systems of crop production. Critic. Rev. Plant Sci. 2000, 19, 1-30. [CrossRef]

24. Adachi, K.; Nakatani, M.; Mochida, H. Isolation of an endophytic diazotroph, Klebsiella oxytoca, from sweet potato stems in Japan. Soil Sci. Plant Nutr. 2002, 48, 889-895. [CrossRef]

25. Asis, C.A.; Adachi, K. Isolation of endophytic diazotroph Pantoea agglomerans and nondiazotroph Enterobacter asburiae from sweet potato stem in Japan. Lett. Appl. Microbiol. 2004, 38, 19-23. [CrossRef]

26. Khan, Z.; Doty, S.L. Characterization of bacterial endophytes of sweet potato plants. Plant Soil 2009, 322, 197-207. [CrossRef]

27. Marques, J.M.; da Silva, T.F.; Vollú, R.E.; de Lacerda, J.R.M.; Blank, A.F.; Smalla, K.; Seldin, L. Bacterial endophytes of sweet potato tuberous roots affected by the plant genotype and growth stage. Appl. Soil Ecol. 2015, 96, 273-281. [CrossRef]

28. Puri, R.R.; Dangi, S.; Dhungana, S.A.; Itoh, K. Diversity and plant growth promoting ability of culturable endophytic bacteria in Nepalese sweet potato. Ad. Microbiol. 2018, 8, 734-761. [CrossRef]

29. Trabelsi, D.; Mhamdi, R. Microbial inoculants and their impact on soil microbial communities: A review. BioMed Res. Int. 2013, 2013, 1-11. [CrossRef] 
30. Conn, V.M.; Franco, C.M. Effect of microbial inoculants on the indigenous actinobacterial endophyte population in the roots of wheat as determined by terminal restriction fragment length polymorphism. Appl. Environ. Microbiol. 2004, 70, 6407-6413. [CrossRef]

31. Gadhave, K.R.; Devlin, P.F.; Ebertz, A.; Ross, A.; Gange, A.C. Soil inoculation with Bacillus spp. modifies root endophytic bacterial diversity, evenness, and community composition in a context-specific manner. Microbial. Ecol. 2018, 76, 741-750. [CrossRef]

32. Ono, K.; Yamanaka, D.; Watanabe, N.U.S. Microorganism. International Patent No. WO99/11756; GB Application No. 09/485,939; U.S. Patent 6,399,056, 4 June 2002.

33. Aizaki, M.; Sumita, A. Effect of hydrophytes on the control of water temperature in model wetland type green roof garden. Environ. Sci. 2005, 18, 535-540.

34. Itoh, K.; Ohashi, K.; Yakai, N.; Adachi, F.; Hayashi, H. Changes in acetylene reduction activities and nifH genes associated with field-grown sweet potatoes with different nursery farmers and cultivars. Horticulturae 2019, 5, 1-9.

35. Elbeltagy, A.; Nishioka, K.; Sato, T.; Suzuki, H.; Ye, B.; Hamada, T.; Isawa, T.; Mitsui, H.; Minamisawa, K. Endophytic colonization and in planta nitrogen fixation by a Herbaspirillum sp. isolated from wild rice species. Appl. Environ. Microbiol. 2001, 67, 5285-5293. [PubMed]

36. Saeki, Y.; Kaneko, A.; Hara, T.; Suzuki, K.; Yamakawa, T.; Nguyen, M.T.; Nagatomo, Y.; Akao, S. Phylogenetic analysis of soybean-nodulating rhizobia isolated from alkaline soils in Vietnam. Soil Sci. Plant Nutr. 2005, 51, 1043-1052.

37. Weisburg, W.G.; Barns, S.M.; Pelletier, D.A.; Lane, D.J. 16S Ribosomal DNA amplification for phylogenetic study. J. Bacteriol. 1991, 173, 697-703. [PubMed]

38. Poly, F.; Monrozier, L.J.; Bally, R. Improvement in the RFLP procedure for studying the diversity of nifH genes in communities of nitrogen fixers in soil. Res. Microbiol. 2001, 152, 95-103.

39. Adhikari, D.; Kaneto, M.; Itoh, K.; Suyama, K.; Pokharel, B.B.; Gaihre, Y.K. Genetic diversity of soybean-nodulating rhizobia in Nepal in relation to climate and soil properties. Plant Soil 2012, 357, $131-145$.

40. Altschul, S.F.; Madden, T.L.; Schäffer, A.A.; Zhang, J.; Zhang, Z.; Miller, W.; Lipman, D.J. Gapped BLAST and PSI-BLAST: A new generation of protein database search programs. Nucleic Acids Res. 1997, 25, 3389-3402.

41. Larkin, M.A.; Blackshields, G.; Brown, N.P.; Chenna, R.; McGettigan, P.A.; McWilliam, H.; Valentin, F.; Wallace, I.M.; Wilm, A.; Lopez, R.; et al. Clustal W and Clustal X version 2. Bioinformatics 2007, 23, 2947-2948.

42. Felici, C.; Vettori, L.; Giraldi, E.; Forino, L.M.C.; Toffanin, A.; Tagliasacchi, A.M.; Nuti, M. Single and co-inoculation of Bacillus subtilis and Azospirillum brasilense on Lycopersicon esculentum: Effects on plant growth and rhizosphere microbial community. Appl. Soil. Ecol. 2008, 40, 260-270.

43. Valenzuela-Soto, J.H.; Estrada-Hernandez, M.G.; Ibarra-Laclette, E.; Delano-Frier, J.P. Inoculation of tomato plants (Solanum lycopersicum) with growth-promoting Bacillus subtilis retards whitefly Bemisia tabaci development. Planta 2010, 231, 397-410. [PubMed]

44. Qiao, J.; Yu, X.; Liang, X.; Liu, Y.; Borriss, R.; Liu, Y. Addition of plant-growth-promoting Bacillus subtilis PTS-394 on tomato rhizo- sphere has no durable impact on composition of root microbiome. BMC Microbiol. 2017, 17, 131.

45. Nascimento, F.X.; Hernández, A.G.; Glick, B.R.; Rossi, M.J. Plant growth-promoting activities and genomic analysis of the stress-resistant Bacillus megaterium STB1 a bacterium of agricultural and biotechnological interest. Biotechnol. Rep. 2019, 25, e00406. [CrossRef] [PubMed]

46. Weifang, X.; Wang, F.; Zhang, M.; Ou, T.; Wang, R.; Strobel, G.; Xiang, Z.; Zhou, Z.; Xie, J. Diversity of cultivable endophytic bacteria in mulberry and their potential for antimicrobial and plant growth-promoting activities. Microbiol. Res. 2019, 229, 126328.

47. Chowdhury, S.P.; Dietel, K.; Ranndler, M.; Schmid, M.; Junge, H.; Borriss, R.; Hartmann, A.; Grosch, R. Effects of Bacillus amyloliquefaciens FZB42 on lettuce growth and health under pathogen pressure and its impact on the rhizosphere bacterial community. PLoS ONE 2013, 8, e68818. [CrossRef]

48. Zhao, L.; Xu, Y.; Lai, X.H.; Shan, C.; Deng, Z.; Ji, Y. Screening and characterization of endophytic Bacillus and Paenibacillus strains from medicinal plant Lonicera japonica for use as potential plant growth promoters. Braz. J. Microbiol. 2015, 46, 977-989.

49. Yu, X.; Ai, C.; Xin, L.; Zhou, G. The siderophore-producing bacterium, Bacillus subtilis CAS15, has a biocontrol effect on Fusarium wilt and promotes the growth of pepper. Eur. J. Soil Biol. 2011, 47, 138-145. 
50. Khedher, S.B.; Kilani-Feki, O.; Dammak, M.; Jabnoun-Khiareddine, H.; Daami-Remadi, M.; Tounsi, S. Efficacy of Bacillus subtilis V26 as a biological control agent against Rhizoctonia solani on potato. Comptes Rendus Biol. 2015, 338, 784-792. [CrossRef]

51. Dutta, S.; Rani, T.S.; Podile, A.R. Root exudate-induced alterations in Bacillus cereus cell wall contribute to root colonization and plant growth promotion. PLoS ONE 2013, 8, e78369.

52. Sharaf-Eldin, M.; Elkholy, S.; Fernandez, J.A.; Junge, H.; Cheetham, R.; Guardiola, J.; Weathers, P. Bacillus subtilis FZB24 (R) affects flower quantity and quality of saffron (Crocus sativus). Planta Med. 2008, 74, 1316.

53. Lacey, L.A.; Frutos, R.; Kaya, H.K.; Vail, P. Insect pathogens as biological control agents: Do they have a future? Biol. Control 2001, 21, 230-248. [CrossRef]

54. Paulitz, T.C.; Belanger, R.R. Biological control in greenhouse systems. Ann. Rev. Phytopathol. 2001, 39, 103-133.

55. Singh, B.K.; Dawson, L.A.; Macdonald, C.A.; Buckland, S.M. Impact of biotic and abiotic interaction on soil microbial communities and functions: A field study. Appl. Soil Ecol 2009, 41, 239-248. [CrossRef]

56. Hardoim, P.R.; Overbeek, V.L.S.; Elsas, J.D.V. Properties of bacterial endophytes and their proposed role in plant growth. Trends Microbiol. 2008, 16, 463-471. [CrossRef]

57. Puri, R.R.; Adachi, F.; Omichi, M.; Saeki, Y.; Yamamoto, A.; Hayashi, S.; Itoh, K. Culture-dependent analysis of endophytic bacterial community of sweet potato (Ipomoea batatas) in different soils and climates. J. Adv. Microbiol. 2018, 13, 1-12. [CrossRef]

58. Marques, J.M.; Da Silva, T.F.; Vollu, R.E.; Blank, A.F.; Ding, G.-C.; Seldin, L.; Smalla, K. Plant age and genotype affect the bacterial community composition in the tuber rhizosphere of field-grown sweet potato plants. FEMS Microbiol. Ecol. 2014, 88, 424-435. [CrossRef]

59. Dalmastri, C.; Chiarini, L.; Cantale, C.; Bevivino, A.; Tabacchiono, S. Soil type and maize cultivar affect the genetic diversity of maize root-associated Burkholderia cepacia populations. Microb. Ecol. 1999, 38, 273-284. [CrossRef]

60. Miller, H.J.; Henken, G.; Van Veen, J.A. Variation and composition of bacterial populations in the rhizosphere of maize, wheat and grass cultivars. Can. J. Microbiol. 1989, 35, 656-660. [CrossRef]

61. Fromin, N.; Achouak, W.; Thiery, J.M.; Heulin, T. The genotypic diversity of Pseudomonas brassicacearum populations isolated from roots of Arabidopsis thaliana: Influence of plant genotype. FEMS Microbiol. Ecol. 2001, 37, 21-29. [CrossRef]

62. Germida, J.J.; Siciliano, S.D.; Renato, D.F.J.; Seib, A.M. Diversity of root-associated bacteria associated with field-grown canola (Brassica napus L.) and wheat (Triticum aestivum L.). FEMS Microbiol. Ecol. 1998, 26, 43-50. [CrossRef]

63. Tian, B.; Zhang, C.; Ye, Y.; Wen, J.; Wu, Y.; Wang, H.; Li, H.; Cai, S.; Cai, W.; Cheng, Z.; et al. Beneficial traits of bacterial endophytes belonging to the core communities of the tomato root microbiome. Agric. Ecosyst. Environ. 2017, 247, 149-156. [CrossRef]

64. Souza, S.A.; Xavier, A.A.; Costa, M.R.; Cardoso, A.M.S.; Pereira, M.C.T.; Nietsche, S. Endophytic bacterial diversity in banana "Prata Anã" (Musa spp.) roots. Gene Mol. Biol. 2013, 36, 252-264. [CrossRef] [PubMed]

65. Xia, Y.; Greissworth, E.; Mucci, C.; Williams, M.A.; Bolt, S.D. Characterization of culturable bacterial endophytes of switchgrass (Panicum virgatum L.) and their capacity to influence plant growth. GCB Bioenergy 2013, 5, 674-682. [CrossRef]

66. Liu, B.; Qiao, H.; Huang, L.; Buchenauer, H.; Han, Q.; Kang, Z.; Gong, Y. Biological control of take-all in wheat by endophytic Bacillus subtilis E1R-j and potential mode of action. Biol. Control 2009, 49, 277-285. [CrossRef]

Publisher's Note: MDPI stays neutral with regard to jurisdictional claims in published maps and institutional affiliations. 